\title{
Penggunaan Strategi Mind Mapping Untuk Meningkatkan Penguasaan Konsep Siswa
}

\author{
Widia $^{1)}$, Fitria Sarnita ${ }^{2)}$, Fathurrahmaniah ${ }^{3)}$, Jessy Parmawati Atmaja ${ }^{4)}$ \\ ${ }^{1 \& 3}$ Pendidikan IPA, STKIP Harapan Bima \\ ${ }^{2}$ Pendidikan Fisika, STKIP Taman Siswa Bima \\ ${ }^{4}$ Pendidikan Guru Sekolah Dasar, STKIP Harapan Bima \\ Email: widia.fisika09@gmail.com ${ }^{1}$, fathurrahmaniah@gmail.com ${ }^{2}$,fitriasarnita21@ gmail.com ${ }^{3}$, \\ jessyparmawatiatmaja@habi.ac.id ${ }^{4}$
}

\begin{abstract}
Abstrak
Tujuan dari penelitian ini adalah ingin mengetahui sejauh mana peran strategi mind mapping mampu meningkatkan penguasaan konsep siswa, sehingga peneliti berinisiatif untuk melakukan penelitan dengan stragi tersebut. Penelitian ini dilakukan pada siswa kelas X MA Nurul Haq Desa Rite Kecamatan Ambalawi dengan jumlah siswa 20 orang dengan jenis penelitan tindakan kelas (PTK). Tindakan dilakukan dengan 2 siklus dengan prosedur penelitian; Perencanaan (Plan), Pelaksanaa (Act). Observasi (Observe) \& Refleksi (Reflect). Hasil penelitian menunjukkan ada peningkatan penguasaan konsep siswa, dimana pada siklus I siswa yang tuntas 12 orang dengan persentasi $60 \%$ sedangkan pada siklus II terjadi peningkatan yang signifikan menjadi 17 orang yang tuntas, artinya $85 \%$ siswa dapat menguasai konsep IPA yang diajarakan. Indikator ini dikatakan berhasil karena sudah memenuhi tuntutan kentuntasan klasikal (KK) yang ditentukan oleh sekolah yaitu $80 \%$. Selain peningkatan pada penguasaan konsep, aktivitas siswa lebih aktif dari biasanya, serta seluruh siswa memberikan respon positif terhadap proses pembelajaran yang berlangsung.
\end{abstract}

Kata kunci: Mind Mapping \& Penguasaan Konsep

\begin{abstract}
The purpose of this study is to find out the extent to which the role of mind mapping strategy can improve students' mastery of concepts so that researchers take the initiative to research with this study. This research was conducted on the tenth-grade students of MA Nurul Haq, Rite Village, Ambalawi District, with a total of 20 students with the type of classroom action research (PTK). The action was carried out in 2 cycles with research procedures; Planning (Plan), Execution (Act). Observation (Observe) \& Reflection (Reflect). The results showed that there was an increase in students' mastery of concepts, wherein cycle I 12 students completed with a percentage of $60 \%$, while in cycle II there was a significant increase to 17 people who completed, meaning that $85 \%$ of students could master the science concept being taught. This indicator is said to be successful because it has met the demands of classical completeness $(K K)$ determined by the school, namely $80 \%$. In addition to an increase in concept mastery, student activities were more active than usual, and all students responded positively to the learning process that was taking place.
\end{abstract}

Keywords: Mind Mapping \& Mastery of Concepts

\section{PENDAHULUAN}

Penelitian tindakan kelas (PTK) merupakan penelitian yang diprakarsai untuk memecahkan masalah dalam proses belajar mengajar di kelas secara langsung. Dengan melaksanakan PTK guru menjadi kreatif, melakukan upaya-upaya inovasi sebagai implementasi dan adaptasi berbagai teori, strategi dan teknik pembelajaran serta bahan ajar yang digunakannya. Penerapan PTK dalam pendidikan dan pembelajaran memiliki tujuan untuk memperbaiki dan atau meningkatkan kualitas praktek pembelajaran secara berkesinambungan sehingga meningkatan mutu hasil instruksional; mengembangkan keterampilan guru; meningkatkan relevansi; meningkatkan efisiensi 
pengelolaan instruksional serta menumbuhkan budaya meneliti pada komunitas guru. Dengan kata lain, PTK dibuat dengan tujuan untuk meningkatkan dan memperbaiki mutu proses belajar mengajar di kelas serta membantu memberdayakan guru dalam memecahkan masalah pembelajaran di sekolah (Mu'alimin, 2014).

Dewasa ini kurikulum pendidikan selalu berkembang dan berinovasi kearah yang lebih baik, meningkatkan kemampuan kognitif, sikap dan keterampilan. Dengan kata lain pembelajaran yang berlangsung di kelas harus berorientasi pada keterampilan seperti keterampilan kerja ilmiah dan kerja sosial. Disisi lain, siswa selalu disuguhkan dengan bahan pembelajaran jadi, konsep-konsep instan dan pembelajaran bisa diakses dimana saja. Namun pada hakikatnya pembelajaran dihanya sampai disitu, siswa dilatih untuk membuat dan mengembangkan ide dengan membuat pertanyaan-pertanyaan sederhana, disajikan dalam bentuk diagram atau gambar. Artinya siswa sendiri yang membuat peta konsep sesuai dengan pikiran mereka sendiri, yang kita kenal dengan peta pikiran (mind mapping). Sehingga siswa menjadi lebih aktif, eksploratif dalam kegiatan pembelajaran dan guru berperan sebagai fasilitator atau moderator. Menurut Windura (2013) Mind Mapping adalah sistem belajar dan berpikir yang mencerminkan secara visual apa yang terjadi pada otak anda saat anda belajar dan berpikir.

Berdasarkan uraian tersebut di atas, maka peneliti ingin menggunakan strategi mind mapping untuk meningkatkan penguasaan konsep siswa pada mata pelajaran IPA kelas $\mathrm{X}$ MA Nurul Haq.

\section{A. Mind Mapping}

Mind mapping adalah cara mencatat yang kreatif, efektif dan secara harfiah untuk memetakan pikiran-pikiran kita (Sulichah, E. 2018). Juga menuntut siswa untuk belajar lebih aktif sehingga pembelajaran tidak hanya berpusat pada guru (Devi. R.S., Yuliariatiningsih \& Mulyati. 2015). Siswa dilatih untuk mengkonstruksi pemahamannya melalui mind mapping yang dibuat berdasarkan permasalahan yang disajikan oleh guru. Catatan yang dibuat membentuk gagasan yang saling berkaitan dengan topik utama di tengah dan subtopik serta perincian menjadi cabangcabangnya. Dengan demikian penggunaan Mind mapping melatih perserta didik membiasakan diri untuk membaca poin penting serta dapat menulis kata kunci dari teks yang dibacanya, baik dengan menggunakan gambar atau simbol untuk memudahkan peserta didik dalam menguasai kkonsep.

Menurut Bobbi Deporter dan Mike Hernacki (2011) Mind mapping memiliki manfaat antara lain: 1) fleksibel, ketika guru atau orang lain menjelaskan materi, siswa dengan mudah menambahkannya di tempat yang sesuai dalam Mind mapping mereka tanpa kebingungan; 2) memusatkan perhatian karena menggunakan Mind mapping tidak perlu menangkap setiap kata yang dijelaskan dari guru atau orang lain, cukup dengan menangkap gagasan utama yang disampaikan; 3) meningkatkan pemahaman; dan 4) menyenangkan karena Mind mapping mengkombinasikan kreativitas dan imajinasi siswa yang tidak terbatas, hal ini lebih menyenangkan apabila dibandingkan dengan membuat catatan biasa. Teknik Mind mapping ditemukan oleh pakar memori dari Inggris pada tahun 1970 Tony Buzan menemukan teknik pencatatan yang didasarkan pada riset bagaimana cara kerja otak sebenarnya (Buzan T. 2011). Otak ternyata mengolah informasi dan menyimpan informasi tidak secara linear, setahap-demi setahap, tetapi otak menyimpan informasi dan memproses informasi secara acak dan otak menyimpan informasi dalam bentuk gambar, simbol, suara, dan bukan dalam bentuk huruf dan tulisan. Hasil penelitian Ayed Al- Zyoud A et al (2017) menunjukkan efek positif dari strategi mind mapping pada kinerja menulis.

\section{B. Penguasan Konsep}

Konsep didefinisikan sebagai kumpulan stimulus (fakta, benda peristiwa, dll) yang memiliki ciri yang sama. (Ibrahim, 2012). Pemahaman tentang konsep amat penting bagi setiap orang. Belajar konsep merupakan hasil utama pendidikan. Konsep merupakan batu pembangun berpikir. Konsep merupakan dasar bagi proses mental yang lebih tinggi untuk merumuskan prinsip dan generalisasi (Dahar, 2011). Untuk memecahkan masalah, seorang 
siswa harus mengetahui aturan-aturan yang relevan dan aturan-aturan ini didasarkan pada konsep-konsep yang diperolehnya. Betapa pentingnya memahami konsep bagi kita dapat dilihat dari dicantumkanya pemahaman terhadap konsep pada kurikulum setiap jenjang pendidikan.

Menurut Gagne, Brings dan Warner (dalam Ibrahim. 2012) pengusaan konsep adalah kemampuan yang mungkin seseorang dapat berbuat sesuatu. Seseorang yang memiliki penguasaan konsep yang baik, luas, dan mendalam seperti yang dimiliki oleh pakar bidang ilmu tertentu, memungkinkan seseorang atau pakar yang bersangkutan menerapkan penguasaanya dalam berbagai keperluan. Menurut Bloom dalam Susanto (2013) pengusaan konsep diartikan sebagai kemampuan untuk menyerap arti dari materi atau bahan yang dipelajari. Hal ini berkaitan dengan seberapa besar mampu menerima, menyerap dan memahami pelajaran yang diberikan oleh guru kepada siswa., atau sejauh mana siswa dapat memahami serta mengerti apa yang ia baca, yang dilihat, yang dialami, atau yang ia rasakan berupa hasil penelitian atau observasi langsung yang ia lakukan. Dari pengertian penguasaan konsep dua tokoh di atas dapat disimpulkan bahwa penguasaan konsep adalah kemampuan untuk menyerap arti dari materi yang dipelajari sehingga memungkinkan seseorang yang bersangkutan menerapkan penguasaanya dalam berbagai keperluan.

Menurut Ausuble (dalam Dahar, 2011) konsep diperoleh dengan dua cara, yaitu pembentukan konsep dan asimilasi konsep. Pembentukan konsep merupakan bentuk perolehan konsep sebelum anak-anak masuk sekolah. Pembentukan konsep dapat disamakan dengan belajar konsep konkret. Pembentukan konsep merupakan proses induktif. Bila anak dihadapkan pada stimulus lingkungan, ia mengabstraksi sifat atau atribut tertentu yang sama dari berbagai stimulus. Asimilasi konsep merupakan cara utama untuk memperoleh konsep selama dan sesudah sekolah. Berlawanan dengan pembentukan konsep yang bersifat induktif, asimilasi bersifat deduktif. Dalam asimilasi konsep anak akan belajar arti konseptual baru dengan memperoleh penyajian atribut-atribut kriteria konsep, kemudian mereka menghubungkan atribut-atribut ini dengan gagasan-gagasan relevan yang sudah ada dalam struktur kognitif mereka. penguasaan konsep dalam proses belajar mengajar sangat mempengaruhi sikap, keputusan dan cara menyelesaikan masalah.

Menurut Ibrahim (2011), penguasaan konsep amat penting bagi setiap orang, menguasai konsep dengan baik, luas dan mendalam, memungkinkan seseorang dapat menerapkan penguasaannya dalam berbagai keperluan. Penguasaan konsep merupakan kemampuan yang memungkinkan seseorang dapat berbuat sesuatu. Hal ini dapat diartikan bahwa tanpa menguasai konsep tertentu, seseorang tidak dapat berbuat banyak dan mungkin kelangsungan hidupnya akan terganggu. Salah satu kemampuan proses mental yang diperlukan dalam memahami konsep adalah kemampuan berpikir.

\section{METODE PENELITIAN}

Jenis penelitian ini adalah penelitian tindakan kelas (PTK) subjek penelitian adalah kelas X MA Nurul Haq, Desa Rite, Kecamatan Ambalawi, Bima NTB. Skenario tindakan pembelajaran dilakukan 2 siklus, dengan prosedur penelitian; Perencanaan (Plan), Pelaksanaa (Act). Observasi (Observe) \& Refleksi (Reflect). Siklus PTK sebegai berikut:

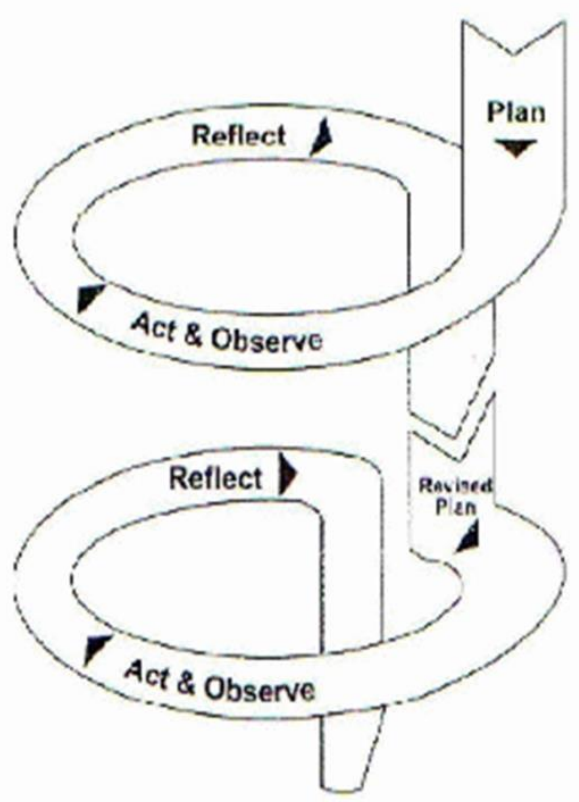

Gambar 1. Siklus PTK 
Data pada penelitian ini diperoleh dari hasil tes siswa, observasi dan respon siswa. Tes diberikan dengan instrumen soal PG, aktivitas siswa dan guru diperoleh dari lembar observasi sedangkan untuk respon siswa diperoleh dari hasil angket respon siswa selama proses pembelajaran menggunakan mind mapping.

Indikator capaian penelitian ini adalah (1) Apabila 85\% siswa memperoleh nilai minimal 70 dengan rentang nilai 0 - 100; (2). Nilai aktivitas siswa minimal mencapai 70\%, serta (3) Siswan memberikan Respon positif minimal 70\%. Jika semua indikator tersebut belum tercapai pada siklus I maka akan dilanjutkan pada tahap siklus II dan

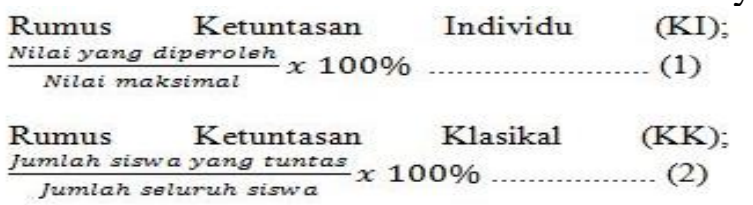

\section{HASIL DAN PEMBAHASAN}

Dari hasil analisis proses penelitan tindakan kelas ini, pada tahapan perencanaan; dimana guru membuat desain pembelajaran atau rencana pelaksanaan pembelajaran (RPP), LKS dan Instrumen dengan strategi mind mapping bertujuan untuk menguku tingkat penguasaan konsep siswa. Setelah melalui proses validasi konten dan kontruk dari perangkat pembelajaran tersebut. Maka tahap selanjutnya adalah penerapan pembelajan di kelas menggunakan perangkat pembelajaran yang sudah didesain menggunakan strategi mind mapping, sehingga data hasil penguasaan konsep siwa pada siklus I sebagai berikut:

\section{A. Siklus I}

\section{Data Hasil Penguasaan Konsep Siswa}

Tabel 1. Hasil Penguasaan Konsep Siswa pada Siklus I

\begin{tabular}{lc}
\hline Kategori & Hasil Belajar Siklus I \\
\hline Nilai Tertinggi & 85 \\
Nilai Terendah & 50 \\
Nilai Rata-Rata & 70,5 \\
Rentang nilai & 35 \\
Tuntas KKM & 12 \\
Tidak tuntas KKM & 8 \\
\hline
\end{tabular}

Tabel 2. Distribusi Frekuensi Pemahaman konsep Siswa pada Siklus I

\begin{tabular}{cc}
\hline Interval & Frekuensi \\
\hline $50-59$ & 3 \\
$60-69$ & 5 \\
$70-79$ & 5 \\
$80-89$ & 7 \\
\hline
\end{tabular}

Hasil pemahaman konsep siswa pada Siklus I setelah dinilai memiliki sebaran nilai tertinggi 85 dan nilai teredah 50, sehingga rentan nilai 20 orang siswa adalah 35. Dengan panjang kelas 10 dan banyak keasnya adalah 4. Setelah dilakukan perhitungan Ketuntasan Individu berdasarkan KKM Sekolah $=70$, maka terdapat 12 siswa yang memenuhi target itu, artinya sebanyak 12 orang siswa yang tuntas, artinya $60 \%$ siswa menguasi konsep IPA yang dipembelajarkan. Namun berdasarkan indikator Ketuntasan Klasikal 80\%, maka proses pembelajaran harus dilanjutkan pada siklus II. Artinya penguasan konsep siswa belu memenuhi indikator KK yang diinginkan yaitu $80 \%$. Kemudian dilakukan refleksi dan evaluasi hasil pembelajaran yang berlangsung dengan memperhatikan hambatan dan kendala selama proses pembelajaran untuk kemudian dirancang strategi/desain pembelajaran yang tepat sehingga mampu memenuhi indikator KK.

\section{Hasil Analisis Aktivitas dan Respon Siswa}

Berdasarkan hasil observer aktivitas siswa, masih terdapat beberapa siswa yang belum terbiasa dengan stategi pembelajaran Mind Mapping, masi kesulitan dalam merangkai dan menghubungkan konsep satu dengan yang lainnya, masih salah dalam menetukan arah panah, penempatan posisi gambar yang kuran pas dan seterusnya. Indikator aktivitas siswa yang dinilai pada penelitian ini adalah; 1) Kemampuan siswa dalam menentukan ide pokok, 2) Kemampuan siswa dalam menemukan inti kalimat atau kalimat penting, dan 3) Kemampuan siswa dalam membuat mind mapping. Maka hasil pengamatan aktivitas siswa menunjukkan, $60 \%$ siswa melakukan indikator menentukan ide pokok dengak kategori baik, 50\% siswa dapat menentukan inti kalimat atau kalimat penting dengan kategori cukup baik, sedangkan untuk indikator membuat mind mapping hanya $45 \%$ siswa yang mampu membuatnya dengan baik dan benar, secara keseluruhan aktivitas siswa selama proses pembelajaran adalah $51,66 \%$. 
Namun jika ditinjau dari sisi lain, siswa memberikan respon positif terhadap strategi mind mapping yang dingunakan, dengan persentasi $85 \%$ siswa dari 20 orang siswa. Siswa menjadi senang, aktif enjoy dan rileks dalam mengikuti proses pembelajaran yang berlangsung. Mind mapping adalah sebuah sistem pembelajaran yang menawarkan kepada kita untuk dapat memaksimalkan cara belajar peserta didik (Suhartini E et al, 2016)

\section{B. Siklus II}

\section{Data Hasil Penguasaan Konsep Siswa}

Tabel 1. Hasil Penguasaan Konsep Siswa pada Siklus II

\begin{tabular}{lc}
\hline Kategori & Hasil Belajar Siklus I \\
\hline Nilai Tertinggi & 95 \\
Nilai Terendah & 50 \\
Nilai Rata-Rata & 77,55 \\
Rentang nilai & 45 \\
Tuntas KKM & 17 \\
Tidak tuntas KKM & 3 \\
\hline
\end{tabular}

Tabel 2. Distribusi Frekuensi Pemahaman konsep Siswa pada Siklus II

\begin{tabular}{cc}
\hline Interval & Frekuensi \\
\hline $50-59$ & 1 \\
$60-69$ & 2 \\
$70-79$ & 6 \\
$80-89$ & 7 \\
$90-99$ & 4 \\
\hline
\end{tabular}

Perencanaan Tidakan pada Siklus II ini, terdiri dari: (a) Kegiatan Pendahuluan, (b) Kegiatan Inti, Siswa dibagi kelompok terdiri dari 5 siswa (c) evaluasi dan penutup. Hasil pemahaman konsep siswa pada Siklus II dengan nilai tertinggi 95 dan nilai teredah 50, sehingga rentan nilai siswa adalah 45. Dengan panjang kelas 10 dan banyak kelasnya adalah 5. Setelah dilakukan analisis deduktif 17 orang siswa memenuhi stadar KKM Sekolah $=70$, artinya $85 \%$ tuntas dalam menguasi konsep IPA yang dipembelajarkan. Sehingga siswa Kelas X MA Nurul Haq telah memenuhi indikator Ketuntasan Klasikal $80 \%$ yang telah ditetapkan oleh lembaga, maka proses pembelajaran dicukupkan. Setelah dilakukan refleksi terhadap proses tindakan yang dilakukan, maka secara keseluruhan siswa mampu menguasai konsep pembelajaran IPA dengan baik. Seseorang dapat dikatakan menguasai konsep jika orang tersebut benar-benar memahami konsep yamg dipelajarinya (Sumaya, 2014).

Hal ini sejalan dengan hasil penelitian Swadarna (2013) mengemukakan bahwa pembelajaran dengan menggunkana model Mind Mapping dapat memberikan banyak hal yang berkaitan dengan kemampuan penguasaan konsep yang dapat dijadikan sebagi unsur penguat (reinforcement) belajar seperti, menggambar, mewarnai, memberi key images, sehingga proses pembelajaran dapat kondusif, fun, dan reward.

\section{Data Hasil Analisis Aktivitas dan Respon} Siswa

Berdasarkan hasil observer aktivitas siswa, sebahagian besar dari siswa sudah terbiasa dengan stategi pembelajaran Mind Mapping, sudah terlatih dalam merangkai dan menghubungkan konsep satu dengan yang lainnya, mahir dan tepat dalam menetukan arah panah dan penempatan posisi gambar yang menarik dan unik, sehingga enak dipangang mata. Indikator aktivitas siswa yang dinilai pada penelitian ini adalah; 1) Kemampuan siswa dalam menentukan ide pokok, 2) Kemampuan siswa dalam menemukan inti kalimat, dan 3) Kemampuan siswa dalam membuat mind mapping.

Maka hasil pengamatan aktivitas siswa menunjukkan, $90 \%$ siswa melakukan indikator menentukan ide pokok dengak kategori baik, $80 \%$ siswa dapat menentukan inti kalimat atau kalimat penting dengan kategori cukup baik, sedangkan untuk indikator membuat mind mapping hanya $90 \%$ siswa yang mampu membuatnya dengan baik dan benar, secara keseluruhan aktivitas siswa selama proses pembelajaran adalah $86,66 \%$. Sehingga berdampak pada respon siswa terhadap strategi mind mapping yang dingunakan meningkat menjadi $100 \%$. Model pembelajaran ini cukup efektif digunakan dalam pembelajaran utamanya pada pembelajaran IPA sehingga berdampak pada peningkatan penguasaan konsep (Hendawati Y., et al, 2018)

\section{Peningkatan Penguasaan Konsep Siwa}


Hasil analisis dari seluruh rangkaian proses pembelajaran menggunakan strategi mind mapping pada siklus I dan siklus II dapat ditunjukkan dengan Grafik sebagai berikut:

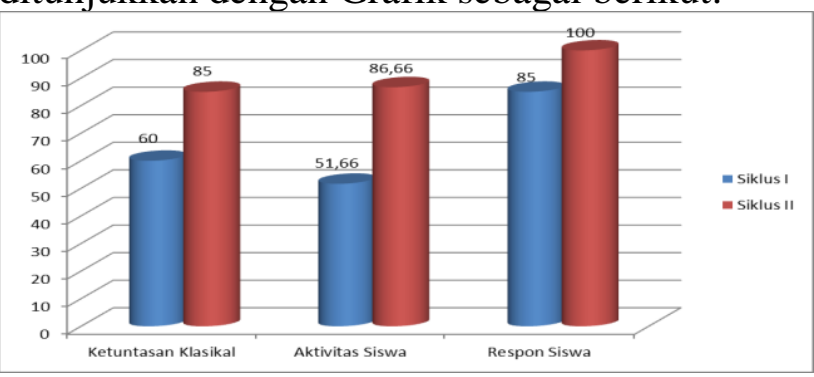

Gambar 2. Diagram Perbandingan Siklus I dan Siklus II

Dari Gambar di atas menunjukan bahwa penggunaan strategi mind mapping dapat meningkatkan penguasaan konsep siswa. Menurut Ciardello dalam Spronken-Smith (2008) menyatakan bahwa siswa akan termotivasi dan bangkit rasa ingin tahunya apabila dihadapkan pada fenomena yang tidak sesuai dengan gambaran yang ada di benaknya. Karena pembelelajarn yang digunakan berbeda dengan pembelajaran yang biasa diterima oleh siswa kelas $\mathrm{X}$ MA Nurul Haq sebelumnya, sehingga merangsan rasa ingin tahu siswa terhadap pembelajaran tersebut. Rasa ingin tahu menurut Piaget dalam Ibrahim (2012) akan memotivasi siswa untuk terlibat aktif dalam pembelajaran serta membangun pemahaman siswa.

\section{KESIMPULAN}

Hasil diskusi dan pembahasan di atas, memberikan kesimpulan bahwa penggunaan strategi mind mapping dapat meningkatkan penguasaan konsep siswa elas X MA Nurul Haq. Dengan indikator (1) Penguasan konsep siswa $85 \%$ dari ketuntasan klasikal $80 \%$ yang ditetapkan oleh sekolah; (2) Ativitas siswa meningkat menjadi $85,66 \%$ dari semula 51,66\%; (3) Seluruh siswa merespon positif pembelajaran yang berlangsung.

\section{SARAN}

- Implikasi dari penelitian ini adalah dapat digunakan oleh guru dalam proses belajar mengajar, sebagai alternatif untuk meningkatkan penguasaan konsep siswa

- Strategi mind mapping dalam penelitian ini terbatas pada pembelajaran IPA saja, sehingga tidak ada jaminan untuk berhasil menigkatkan penguasaan konsep pada mata pelajaran yang lain.

\section{DAFTAR PUSTAKA}

Ayed Al- Zyoud A. Dina Al Jamal \& Abdallah Baniabdelrahman (2017) Mind Mapping and Students' Writing Performance. Arab World English Journal (AWEJ) Vol. 8 No 4. Pp. 28029

Buzan, Tony. (2011). Buku pintar mind map. Jakarta : PT. Gramedia Pustaka Utama

Dahar, W Ratna. (2011). Teori-teori belajar dan pembelajaran. Bandung: Bina aksara

Deporter B \& Mike Hernacki (2013) Quantum Learning Membiasakan Belajar Nyaman dan Menyenangkan. Bandung: Mizan Pustaka

Devi, R. S., Yuliariatiningsih, M. S., \& Mulyati, T. (2015). Efektivitas Metode Mind Mapping Terhadap Peningkatan Pemahaman Konsep Siswa Pada Mata Pelajaran IPA. Jurnal PGSD Kampus Cibiru. Vol. 03. No.02.

Hendawati Y., Suci Utami Putri, Suko Pratomo \& Fitri Widianingsih (2018) Penerapan Model Mind Mapping untuk Meningkatkan Penguasaan Konsep IPA di SD. Metodik Didaktik: Vol. 13 No. 2, pp. 113-124

Ibrahim, M. (2011). Assessmen berkelanjutan, konsep dasar tahapan pengembangan dan contoh. Surabaya: Unesa University Prees.

(2012). Pembelajaran inkuiri. Jakarta : Rhineka Cipta

Mu'alimi (2014) Penelitian tindakan kelas teori dan praktik. Surabaya: Ganding Pustaka.

Subiyanto (1988). Pendidikan ilmu pengetahuan alam. Jakarta: PPLPTK.

Suhartini E, Z.A. Imam Supardi \& Rudiana Agustini (2016) Pengembangan Perangkat Pembelajaran Model Inkuiri Terbimbing Berbantuan Teknik Mind Mapping Untuk Meningkatkan Penguasaan Konsep dan Kemampuan Berpikir Kreatif Siswa SMP. Jurnal 
Penelitian Pendidika sain (JPPS) Vol. 5.

No. 2, pp. 892-902

Sulichah E (2018) Efektivitas Model Pembelajaran Mind Mapping Terhadap Haasil Balajar IPA dan Motovasi Belajar Sisw.a Natural. Jurnal Ilmiah Pendidikan IPA. Vol. 5 No. 2, pp, 7177.

Sumaya. (2014). Sains di SD. Bandung: Erlangga

Spronken-Smith, R. (2008). Experiencing the Process of Knowledge Creation: The Nature and Use of Inquiry-Based Learning in Higher Education. Journal of Research. New Zealand: University of Otago.pp.12-15

Susanto A. (2013). Teori belajar dan pembelajaran di sekolah dasar. Jakarta : PT.Kharisma Putra Utama.

Swadarma, Doni. (2013). Penerapan Mind Mapping dalam Kurikulum Pembelajaran. Jakarta: PT Elex Media Komputindo

Windura S. (2010). Mind Map langkah demi langkah. Jakarta: Eex Media Komputindo. 